\title{
PENGARUH KINERJA KELOMPOK KERJA GURU DAN SUPERVISI RUTINKEPALA SEKOLAH TERHADAP MUTU SEKOLAH
}

\author{
Nurjamilah \\ SMK Negeri 9 Garut \\ Jl. Raya Garut-Bayongbong KM 10 Desa Panembong Kecamatan Bayongbong \\ nurjamilah@smknegeri9garut.sch.id
}

\begin{abstract}
This study aims to analyze the effect of implementing the KKG and routine supervision of the principal on improving the quality of elementary schools, especially in Garut Kota District. The method used in this research is descriptive correlational method. The object of research as well as the population in this research are principals and elementary school teachers in Garut Kota District. Meanwhile, the sample in this study was 137 respondents who were drawn from principals and teachers in a balanced manner. Data collection techniques used are documentation studies, field studies. While the data analysis technique used to answer the hypothesis is statistical analysis with a path analysis model. The results of research on the implementation of the KKG in Garut Kota District have been felt by the teachers to be not optimal, so there needs to be efforts to further improve various activities that are beneficial for the development of teacher professionalism. Routine supervision of school principals shows that in general the principals of elementary schools in Garut Kota District have not fully carried out routine supervision as they should. The quality of the school also shows quite good criteria. The results of testing the research hypothesis can be concluded that the implementation of the KKG and routine supervision of the principal has a positive influence on improving the quality of elementary schools in Garut District, Garut Regency, both individually and simultaneously (simultaneously).
\end{abstract}

Keywords: Teacher Working Group Performance, Principal Routine Supervision, School Quality

\section{ABSTRAK}

Penelitian ini bertujuan untuk menganalisis pengaruh pelaksanaan KKG dan supervisi rutin kepala sekolah terhadap peningkatan mutu sekolah dasar, khususnya di Kecamatan Garut Kota. Metode yang digunakan dalam penelitian ini adalah metode deskriptif korelasional. Objek penelitian dan juga populasi dalam penelitiain ini adalah kepala sekolah dan guru-guru SD di Kecamatan Garut Kota. Sementara itu yang dijadikan sampel dalam penelitian ini sebanyak 137 responden yang diambil dari unsur kepala sekolah dan guru secara berimbang. Teknik pengumpulan data yang dilakukan adalah studi dokumentasi, studi lapangan. Sedangkan teknik analisis data yang digunakan untuk menjawab hipotesis adalah analisis statistic dengan model analisis jalur (path analysis). Hasil penelitian pada pelaksanaan KKG di Kecamatan Garut Kota selama ini dirasakan oleh guru-guru belum optimal, sehingga perlu ada upaya untuk lebih meningkatkan berbagai kegiatan yang bermanfaat bagi pengembangan profesionalisme guru. Supervisi rutin kepala sekolah menunjukkan bahwa secara umum kepala SD yang ada di Kecamatan Garut Kota belum sepenuhnya melaksanakan supervisi secara rutin sebagaimana yang seharusnya. Mutu sekolah juga menunjukkan kriteria cukup baik. Hasil pengujian hipotesis penelitian dapat disimpulkan bahwa pelaksanaan KKG dan supervisi rutin kepala sekolah memiliki pengaruh positif terhadap peningkatan mutu sekolah dasar yang ada di Kecamatan Garut Kota Kabupaten Garut, baik secara sendiri-sendiri maupun secara bersama-sama (simultan).

Kata Kunci : Kinerja Kelompok Kerja Guru, Supervisi RutinKepala Sekolah, Mutu Sekolah 


\section{PENDAHULUAN}

Peningkatan kualitas pendidikan dapat dilakukan dengan berbagai upaya, antara lain perbaikan kurikulum, proses belajar mengajar, kinerja guru, system pendidikan, supervisi kepala sekolah, pemberdayaan kelompok kerja guru, penyediaan sarana dan prasarana, serta upaya-upaya yang lainnya. Dalam upaya-upaya tersebut, perbaikankinerja guru termasuk upaya yang sangat strategis, mengingat guru merupakan ujung tombak dalam keberhasilan mutu pendidikan. Dalam upaya peningkatan mutu pendidikan, guru merupakan komponen sumber daya manusia yang harus dibina dan dikembangkan terus-menerus. Hal ini sependapat dengan Jaccbson[1] yang menyatakan bahwa: “...tidak semua guru yang dididik di lembaga pendidikan terlatih dengan baik dan kualified".

Berbicara mengenai pengembangan sumber daya manusia kata kuncinya adalah "Pendidikan" keunggulan sumber daya manusia hanya mungkin diperoleh melalui pendidikan yang diprogramkan secara sistematik dan terencana. Tinggi rendahnya kualitas sumber daya manusia ditentukan oleh tinggi rendahan kualitas pendidikan yang diperolehnya, sehingga yang berkualitas merupakan momen penting dalam konteks peningkatan kualitas sumber daya manusia. Peran guru sebagai tenaga edukatif mempunyai tanggung jawab di dunia pendidikan, yaitu bahwa guru sebagai motor penggerakn dan perancang serta pencetak bagi generasi mendatang. Guru harus dapat memberikan ilmu pengetahuan dan juga membimbing agar peserta didik dapat mengandalkan ilmunya, baik dalam kapasitas pribadi maupun ditengah masyarakat. Dalam kaitan ini Alfian [2] menyatakan: upaya meningkatkankualitas SDM harus dimulai dari upaya meningkatkan mutu pendidikann yang dibarengidengan upaya meningkatkan kemampuan professional guru. Di samping itu lembaga- lembaga pendidikan tenaga guru (LPTK) atau lembaga lain yang berwenang mempersiapkan tenaga kerja, turut menentukan kualitas pendidikan.

Upaya pengembangan dan peningkatan mutu pendidikan di Indonesia telah dimulai sejak lama, dan lebih giat lagi sejak 1969 dalam Pelita I, melalui proyek-proyek pengembangan dan peningkatakn mutu pendidikan dasar, menengah dan pendidikan tinggi, dengan dana APBN ataupun dana pinjaman luar negeri.

Berkaitan dengan upaya meningkatkan mutu pendidiikan di Indonesia, maka perlu dikaji secara mendalam mengenai beberapa hal yang secara langsung turut menentukan keberhasilan pendidikan yaitu, kinerja edukatif guru sebagai pelaksana kegiatan belajar mengajar, serta kinerja kepala sekolah sebagai pimpinan di sekolah. Masalah kompetensi guru merupakan salah satu yang harus dimiliki oleh setiap guru dalam jenjang pendidikan apapun. Kompetensi yang harus dimiliki oleh setiap guru antara lain kompetensi kepribadian, kompetensi professional dan kompetensi sosial.

Salah satu wujud upaya yang dilakukan pemerintah yang berhubungan dengan peningkatan kualitas dan profesionalisme guru, khususnya pada jenjang pendidikan dasar adalah dibentuknya Kelompok Kerja Guru (KKG). Kelompok Kerja Guru (KKG) yang merupakan wadah professional tenaga kependidikan sekolah dasar yang bersifat aktif, kompak, dan akrab dengan prinsip dari guru, oleh guru, untuk guru dalam pelaksanaan tugasnya di sekolah.

KKG merupakan suatu wadah bagi guru dan kepala sekolah yang bergabung dalam organisasi gugus sekolah yang bertujuan untuk menjadikan guru dan kepala sekolah lebih professional dalam upaya peningkatan pendidikan Sekolah Dasar melalui pendekatan system 
pembinaan professional dan kegiatan belajar mengajar aktif. KKG merupakan wadah kegiatan dalam merencanakan, melaksanakan dan mengevaluasi kegiatan belajar menagajar.

Mengamati fungsi dan tujuan Kelompok Kerja Guru (KKG) tersebut, tampak jelas bahwa keberadaan KKG merupakan satu upaya dalam meningkatkan kualitas dan profesionalitas guru khususnya dalam pelaksanaan pembelajaran. Hal ini didasari oleh suatu keyakinan bahwa kualitas hasil pendidikan, efektivitas sekiolah, dan mutu sekolah sebagian besar akan ditentukan oleh kualitas pembelajaran yang dilakukan guru.

Di lain pihak kepala sekolah merupakan salah satu komponen pendidikan yang paling berperan dalam meningkatkan kualitas pendidikan. Seperti di ungkapkan Supriadi [3] bahwa: "Erta hubungannya antara mutu kepala sekolah dengan berbagai aspek kehidupan sekolah seperti disiplin sekolah. Iklim budaya sekolah, dan merumuskan perilaku nakal peserta didik." Dalam pada itu, kepala sekolah bertanggung jawab atas manajemen pendidikan secara mikro, yang secara langsung berkaitan denganproses pembelajaran di sekolah. Sebagaimana di kemukakan dalam Pasal 12 ayat 1 PP 28 tahun bawah: "Kepala sekolah bertanggung jawab atas penyelengaraan kegiatan pendidikan, administrasi sekolah, pembinaan tenaga kependidikan lainnya, dan pendayagunaan serta pemeliharaan saran dan prasarana [4].

Kutipan tersebut menunjukkan bahwa supervise merupakan suatu proses yang dirancang secara khusus untuk membantu para guru dan supervision dalam mempelajar tugas sehari-hari disekolah; agar dapat menggunakan pengetahuan dan kemampuannya untuk memberikan layanan yang lebih baik pada orang tua peserta didik dan sekolah, serta berupaya menjadikan sekolah sebagai masyarakat belajar yang lebih efektif.

Bertitik tolak dari uraian di atas, penulis tertarik untuk melaksanakan penelitian lebih lanjt dengan pengaruh pelaksana Kelompok Kerja Guru (KKG) dan suoervisi rutin kepala terhadap peningkatan mutu Sekolah Dasar di Kecamatan Garut Kota.

Penelitian ini dilakukan dengan tujuan untuk mengetahui pengaruh pelaksanaan KKG dan supervise rutin yang dilakukan kepala sekolah terhadap peningkatan mutu sekolah. Dari pertanyaan masalah pokok tersebut, maka sub-sub pertanyaan masalah dalam penelitian ini adalah sebagai berikut:

1. Bagaimana pengaruh pelaksanaan Kelompok Kerja Guru (KKG) terhadap peningkatan mutu sekolah?

2. Bagaimana pengaruh pelaksanaan supervise rutin yang dilakukan kepala sekolah terhadap peningkatan mutu sekolah?

3. Bagaimana pengaruh pelaksanaan KKG dan supervise rutin yang dilakukan kepala sekolah terhadap peningkatan mutu sekolah?

\section{KAJIAN PUSTAKA}

\section{Kelompok Kerja Guru (KKG)}

\section{a. Pengertian Kelompok Kerja Guru (KKG)}

Peningkatan mutu pendidikan khususnya pada tingkat Sekolah Dasar (SD) telah menjadi kebijaksanaan pemerintah yang harus diwujudkan dengan sebaik-baiknya. Usaha ini dilaksanakan dalam rangka peningkatan kualitas sumber daya manusia yang berkualitas guna mencapai tujuan pembangunan nasional. Dalam usaha peningkatan mutu pendidikan, khusunya dalam mata pelajaran PKn SD, maka factor guru memegang peranan yang penting, karena itu profesionalisme guru harus digalang secara sistematis dan berencana melalui wadah-wadah pembinaan professional guru. Adapun wadah system pembinaan professional guru itu diantaranya Kelompok Kerja Guru (KKG). 
Sesuai dengan uraian tersebut diatas, maka menurut Peraturan Pemerintah No. 28 Tahun 1990, pasal 30, menyatakan bahwa: "Pengelola satuan pendidikan bertanggungjawab atas pemberian kesempatan kepada tenaga kependidikan yang bekerja disatuan pendidikan yang bersangkutan untuk mengembangkan kemampuan profesional masing-masing.’[4].

Dengan kutipan tersebut, maka melalui kegiatan pada Kelompok Kerja Guru (KKG) yang merupakan wadah kebersamaan tenaga kependidikan dapat menentukan perencanaan dan pelakasanaan program kegiatan belajr mengajar di sekolah atau diluar sekolah serta dapat memecahkan masalah atau kesulitan-kesulitan yang berkaitan dengan fungsi dan tugas pokok guru dalam meningkatkan mutu pendidikan".

\section{b. Peranan Kelompok Kerja Guru (KKG) dalam Meningkatkan Profesionalisme Guru}

1) Pengertian Profesionalisme Guru

Professional guru adalah suatu tenaga kependidikan yang dilaksanakan oleh orangorang ahli di bidang mendidik, membimbing dan mengajar [5]. Keahlian yang dimiliki oleh seorang tenaga kependidikan tidak dimiliki oleh warga masyarakat dalam arti rata-rata, tetapi hanya dimiliki oleh orang-orang tertentu yang telah mengalami pendidikan tenaga kependidikan secara berencana dan sistematis. Dan bahwa hasil pendidikan tidak bisa dilihat manfaatnya dalam waktu yang relative singkat, akan tetapi hasilnya akan dapat dilihat dalam waktu yang relative lama bahkan mungkin setelah satu generasi. Oleh sebab itu maka jangan sampai membuat kesalahan yang dibuat oleh orang awam kendatipun sedikit tentang kependidikan yang bukan ahlinya dalam bidang tersebutm karena akan merusak satu generasi berikutnya akibatnya akan berlanjut terus. Maka tangan-tangan yang mengelola kependidikan haruslah orang-orang yang professional dalam bidang kependidikan. Pekerjaan tenaga kependidikan harus dilakukan oleh orang-orang yang bertugas selaku tenagah ahli kependidikan karena merupakan pekerjaan penuh pengabdian berdasarkan kode etik tertentu [6].

Peranan guru dalam masa depan pembangunan dewasa ini makin penting dan strategis, sebab bidang pendidikan merupakan tempat pengabdian para guru dalam menentukan keberhasilan pembangunan. Tanpa pendidikan yang baik tidak mungkin tumbuh bangsa yang cerdas yang dapat memungkinkan untuk membangun masa depan.

\section{2) Kemampuan Profesional Guru}

Guru memegang peranan penting dan strategis dalam upaya membentuk watak bangsa dan mengembangkan potensi siswa dalam kerangka pembangunan pendidik di Indonesia. Tampaknya kehadiran guru hingga saat ini bahkan sampai akhir hayat nanti tidak akan pernah dapat digantikan oleh yang lain, terlebih pada masyarakat Indonesia yang multicultural dan multibudaya, kehadiran teknologi tidak dapat menggantikan tugas-tugas guru yang cukup komplek dan unik.

Guru sebagai pendidik profesional mempunyai citra yang baik dimasyarakat apabila dapat menunjukkan kepada masyarakat bahwa ia layak menjadi panutan atau teladan masyarakat sekelilingnya sehingga sikap professional guru sangat penting. Menurut Soetjipto sikap professional keguruan meliputi: (a) sikap terhadap peraturan perundang-undangan; (b) sikap terhadap organisasi profesi (c) sikap terhadap teman sejawat; (d) sikap terhadap anak didik; (e) sikap terhadap teman kerja; (f) sikap terhadap pemimpin; (g) sikap terhadap pekerjaan [7].

Standar profesionalisme guru akan membantu mengenali guru yang baik, pengembangan panduan professional, meningkatkan kegiatan belajar mengajar pada tingkat 
sekolah dan meningkatkan tanggung jawab guru. Standarisasi menyediakan sebuah patokan dalam hal, seleksi, promosi, pengembangan profesi dan dukungan bagi guru.

\section{3) Tujuan Peningkatan Profesionalisme Guru}

Peningkatan professional guru merupakan salah satu hal yang harus dilaksanakan dalam jenjang pendidikan apapun oleh tenaga kependidikan.

Adapun tujuan peningkatan professional guru yaitu sebagai berikut:

1. Kompetisi tenaga kependidikan sebagai:

a. Alat seleksi dalam penerimaan calon tenaga kependidikan.

b. Suatu upaya dalam rangka pembinaan

2. Mampu mengembangkan tanggung jawab dengan sebaik-baiknya.

3. Agar selalu peka dan tanggap terhadap perubahan-perubahan

4. Untuk menambah wawasan kemampuan dan keahlian khusus dalam melaksanakan tugas dan fungsinya sebagai tenaga pendidik (guru).

\section{4) Peran KKG dalam Meningkatkan Profesional Guru}

Kehadiran guru sangat menentukan keberhasilan proses belajar mengajar. Ditangan gurulah di antaranya berhasil dan tidaknya, meningkat dan menurunnya proses pendidikan. Untuk itu guru haruslah benar-benar professional sesuai dengan bidang, tugas dan fungsi perannya.

Dengan uraian tersebut diatas, maka guru SD akan mengalami berbagai permasalahan untuk mengatasi berbagai bidang studi. Untuk itu perlu adanya wahana informasi, innovasi, dan pembinaan profesi guru guna memecahkan masalah-masalah yang berkaitan dengan proses pendidikan. Adapun tentang wahana atau tempat tersebut yaitu disebut sebagai Pusat Kegiatan Guru dan kegiatannya disebut Kelompok Kerja Guru (KKG).

Melalui KKG, pelaksanaan pembinaan guru dalam rangka peningkatan proses belajar akan lebih efisien dan efektif. Melalui $\mathrm{KKG}$, maka guru-guru dapat merumuskan dan memcahkan masalah yang dihadapi dilapangan. Hal ini sesuai dengan pendapat A.Tabrani Rusyan [8], mengemukakan bahwa:

Dengan rumusan tersebut diatas, maka tenaga kependidikan di SD yang merupakan guru kelas dan sebagai KKG bidang studi tertentu yang diminatinya, sehingga permasalahan anggota KKG (guru) dalam bidang studi lain yang merupakan tanggung jawabnya akan dapat teratasi karena adanya system pertukaran infomrasi dan hasil KKG dari berbagai bidang studi dan kelas.

Keberhasilan pendidikan itu diantaranya bukan ditentukan oleh peserta didik saja, tetapi gurulah yang menentukan. Untuk itu professional guru haruslah ditingkatkan agar mutu pendidikan itu lebih berkualitas lagi. Tenaga kependidikan di SD merupakan guru kelas yang harus menguasai minimal delapan bidang studi, sehingga banyak permasalahan yang menyangkut masalah proses pendidikan.

\section{Supervisi Pendidikan}

\section{a. Pengertian Supervisi Pendidikan}

Dalam dunia pendidikan di Indonesia, pereataan supervise belum begitu popular. Sejak zaman penjajahan Belanda hingga sekarang lebih dikenal kata "inpeksi" daripada supervise. Pengertian inspeksi sebagai warisan pendidikan Belanda dulu, cenderung kepada pengawsan yang bersifat otokratis, yang berarti mencari kesalahan-kesalahan guru dan kemudian menghukumnya. Sementara itu supervise mengandung pengertian yang lebih demokratis. Dalam pelaksanaannya, supervise bukan hanya mengawasi apakah guru maupun pegawai 
menjalankan tugas dengan sebaik-baiknya sesuai dengan intruksi atau ketentuan-ketentuan yang telah digariskan, tetapi juga berusaha bersama-sama guru bagaimana cara memperbaiki proses pembelajaran. Dengan demikian dalam pelaksanaan supervise, guru tidak dianggap sebagai pelaksana pasir, namun diperlakukan sebagai partner bekerja yang memiliki ide-ide, pendapat, dan pengalaman yang patut untuk didengar, diahargai dan diikutsertakan dalam usaha-usaha perbaikan pendidikan.

Dari rumusan supervise tersebut dapat diartikan bahwa supervisor berada pada posisi yang unik dalam pembelajaran, sebab tugasnya amat strategis untuk mempengaruhi keefektifan interaksi dalam pelayanan belajar oleh guru. Karena itu praktek supervise disekolah didasarkan pada salah satu atau kombinasi dari manajemen ilmiah tradisional, hubungan manusia dilihat dari aspek psikologi dan sosiologi serta komunikasi, dan manajemen ilmiah baru. Manajemen ilmiah tradisional menganut filsafat otokratik klasik dalam supervise dan memandang guru sebagai pelengkap manajemen yang diharapkan melaksanakan tugas sesuai dengan kehendak manajemen, artinya menggunakan fungsi-fungsi manajemen dengan dan terukur.

\section{b. Tujuan Supervisi Pendidikan}

Dari pembahasan supervise pendidikan di atas, maka dapat ditegaskan bahwa tujuan supervise pendidikan antara lain adalah (1) membantu guru-guru dalam mengembangkan proses belajar mengajar; (2) membantu guru-guru menterjemahkan kurikulum kedalam bahasa belajar mengajar; dan (3) membantu guru-guru mengembangkan staf sekolah. Secara umum tujuan sekolah supervise pendidikan membantu guru-guru melihat tujuan pendidikan, membimbing pengalaman belajar menagajar, menggunakan sumber belajar, menggunakan metode mengajar, memenuhi kebutuhan belajar murid, menilai kemajuan belajar murid, membina moral kerja, menyesuaikan diri dengan masyarakat, dan membina sekolah. Adapun tujuan supervise pendidikan menurut Peter F. Olivia adalah: (1) membantu guru dalam mengembangkan proses kkegiatan belajar mengajar, (2) membantu guru dalam menterjemahkan dan mengembangkan kurikulum dalam proses belajar mengajar; (3) membantu guru dalam mengembangkan staf sekolah [9].

Berdasarkan beberapa kajian terhadap pengertian dan hakikat supervise di atas dapat disimpulkan bahwa supervise bertujuan mengembangkan iklim yang kondusif dan lebih baik dalam kegiatan belajar-mengajar, melaluui pembinaan dan peningkatan profesi menagajar. Dengan kata lain, tujuan supervise pengajaran adalah membantu dan memberikan kemudahan kepada para guru untuk belajar bagaimana meningkatkan kemampuan mereka guna meuwujudkan tujuan belajar pserta didik.

Tujuan dan sasaran supervise pendidikan adalah perbaikan dan perkembangan proses belajar-mengajar secara total, ini berarti bahwa tujuan supervise tidak hanya untuk memperbaiki mutu mengajar guru, tapi juga membina pertumbuhan profesi guru dalam arti luas, termasuk didalamnya pengadaan fasilitas-fasilitas, pelayanan kepemimpinan dan pembinaan human relation yang baik kepada semua pihak yang terkait [10] (Qodry A. Azizy, 2004:28)

\section{c. Teknik Supervisi}

Ada tersedia sejumlah teknik supervise yang dipandang bermanfaat untuk merangsang dan mengarahkan perhatian guru-guru terhadap kurikulum dan pengajaran. Untuk mengidentifikasi masalah-masalah yang bertalian dengan mengajar dan belajar kemudian untuk menganalisis kondisi-kondisi yang mengelilingi mengajar dan belajar. Teknik supervise terdiri dari: 1) teknik individual dalam rangka pengembangan proses belajar mengajar meliputi kunjungan kelas, observasi kelas, percakapn pribadi, saling mengunjungi kelas dan menilai diri sendiri; dan 2) teknik supervise kelompok dalam rangka pengembangan staf meliputi pertemuan orientasi bagi 
guru baru, panitia penyelenggara, rapat guru, studi guru, diskusi sebagai proses kelompok, tukar menukar pengalaman, lokakaryya, diskusi panel, seminar symposium, demonstration teaching, perpustakaan jabatan, bulletin supervise, membaca langsung, mengikuti kursu, organisasi jabatan, currulum laboratory, perjalanan sekolah.

\section{Mutu Sekolah}

\section{a. Pengertian Mutu Sekolah}

Penilaian terhadap kelayakan dan kinerja yang dilakukan secara terus menerus dalam rangka melakukan secara berkesinambungan perbaikan dan peningkatan mutu sekolah tidak dapat dilepaskan kaitannya dengan manajemen, khususnya manajemen mutu sekolah. Dalam manajemen mutu ini semua fungsi manajemen yang dijalankan oleh manajer pendidikan di sekolah diarahkan untuk memberi kepuasan kepada pelanggannya, baik pelanggan internal yaitu guru dan tenaga kependidikan serta tenaga administrative, pelanggan eskternal yang rimer yaitu siswa yang sekunder yaitu pemerintah, orang tua atau masyrakat yang membiayai pendidikan, dan pelanggan tersier yaitu lembaga atau para pemakai lulusan. Semua ini dilaksanakan agar penyelenggara pendidikan dapat memberi jaminan kepada para pelanggannya bahwa pendidikan yang diselenggarakannya adalah pendidikan bermutu.

Berdasarkan uraian diatas jelas bahwa dengan peningkatakan kualitas sumber daya manusia peningkatan mut pendidikan sangat besar perananya dalam meningkatkan sumber daya manusia sebagai peningkatan kualitas kinerja.

\section{b. Karakteristik Mutu Sekolah}

Sekolah yang bermutu adalah sekolah yang memiliki penilaian terhadap berbagai hal yang berhubungan dengan sekolah yang baik. Oleh karena itu tolak ukur penilaian mutu sekolah dalam penelitian ini ditemukan dengan kriteria akreditasi. Standar akreditasi sekolah adalah kriteria tertentu yang harus dipenuhi sesuai dengan komponen-komponen pendidikan pada setiap jenis pendidikan TK, SD, SDLB, SMP, SMPLB, SMA, SMK, SMLB. Setiap sekolah harus memenuhi standar minimal yang telah ditetapkan oleh Badan Akreditasi Sekolah (BASNAS). Sekolah yang memenuhi standar minimal akan dinyatakan terakreditasi dan yang tidak memenuhi dinyatakan tidak terakreditasi. Karena standar yang digunakan untuk mengakreditasi sekolah adalah standar minimal, BASNAS mendorong agar sekolah mencapai standar yang lebih tinggi. Mengingat stsndar merupakan sesuatu yang bersifat dinamis sejalan dengan perkembangan dan tuntutan, maka tingkatan standar juga akan berubah sesuai dengan perkembangan dan tuntutan pendidikan dimasa depan.

\section{METODE PENELITIAN}

\section{A. Metode Penelitian}

Metode penelitian berkaitan dengan penyusunan kondisi-kondisi untuk mengumpulkan dan menganalisis data dengan cara memadukan kaitan (relevansi) tugas penelitian dengan aspek-asoek ekonomi dalam prosedurnya. Metode yang digunakan dalam penelitian ini adalah deskriptif analisis yang ditujukan untuk membuat deskripsi, gambaran atau lukisan secara sistematis, faktula dan akurat mengenai fakta-fakta dan sifat-sifat fenomena yang diselidiki.

Berdasarkan bentuk permasalahannya penelitian ini termasuk penelitian deskriptif korelasional karena semua variable yang dipelajari terlebih dahulu didiskusikan dan selanjutnya 
dikorelasikan antara variable bebas dengan variable terkait, baik secara sendiri-sendiri maupun bersama-sama.

\section{B. Sampel Penelitian}

Dalam penelitian ini menggunakan teknik random sampling, yaitu adanya kesempatan yang sama bagi anggota populasi untuk terpilih sebagai sampel. [11] (Iskandar ,2005 : 231)

Melihat karakteristik dan penyebaran dari populasi penelitian, maka penarikan sampelnya bersifat cluster random sampling, adalah teknik pengambilan sampel dari kelompokkelompok atau unit-unit populasi berdasarkan area atau cluster, dalam penelitian ini populasi bervariasi dalam starata social yang berada seperti Guru dan Kepala Sekolah.

Ukuran sampel ditentukan berdasarkan Slovin [11] (Iskanda : 105) yaitu :

$$
n=\frac{N}{1+N(e)^{2}}
$$

Jumlah Sampel Penelitian Berdasarkan Kelompok Populasi

\begin{tabular}{|c|c|c|c|}
\hline No & Kelompok Populasi & Jumlah Populasi & Jumlah Sampel \\
\hline 1. & Kepala Sekolah & 85 orang & $\frac{9}{1+(85)(10 \%)^{2}}=46$ \\
\hline 2. & Guru-guru & 1062 ornag & $\frac{1062}{1+(1062)(10 \%)^{2}}=91$ \\
\hline \multicolumn{2}{|c|}{ Jumlah } & 1147 orang & 137 \\
\hline
\end{tabular}

\section{Teknik dan Alat Pengumpul Data}

\section{Teknik Pengumpul Data}

Adapun teknik pengumpulan data yang penulis gunakan dalam penelitian ini adalah sebagai berikut:

\section{a. Studi Dokumentasi}

Teknik ini dilakukan dengan cara mempelejari baik buku-buku literature (logic relational) maupun dokumen-dokumen resmi seperti peraturan-peraturan dan kebijakan-kebijakan (legal formal) yang berakitan dengan $\mathrm{KKG}$, supervise kepala sekolah dan mutu sekolah.

\section{b. Studi Lapangan}

- observasi atau pengamatan dilakukan dengan mengamati kondisi objektif sekolah dasar yang menjadi sampel penelitian, yaitu pelaksanaan KKG, supervise kepala sekolah dan mutu sekolah.

- Angket, teknik ini dilakukan dengan cara mengedarkan daftar pertanyaan (kuisioner) untuk diisi oleh responden yang menjadi sampel dalam penelitian yang berkaitan dengan pelaksanaan KKG, supervise kepala sekolah dan mutu sekolah.

\section{Alat Pengumpulan Data}

\section{a. Alat Ukur Penelitian}

Dalam penelitian ini, alat ukur yang digunakan berupa kuesioner dibuat secara terstruktur, didalamnya meliputi beberapa item pertanyaan yang disertai alternative jawaban. Dengan demikian maka responden tinggal memilih salah satu jawaban sesuai dengan jawaban sebenarnya.

Kuesioner tersetruktur ini dibuat mengingat satuan pengukuran yang digunakan adalah skoring, yaitu pemberian nilai skor pada setiap alternative jawaban yang 
disediakan dalam pertanyaan penelitian. Tingkat pengukuraan variable penelitian ini adalah ordinal dan kategori jawaban yang bersifat tertutup terdiri dari 5 (lima) pilihan dengan menggunakan skala perbedaan semantic.

\section{b. Pengujian Validitas Alat Ukur Penelitian}

Pengujian validitas alat ukut penggunaan penelitian dapat menunjukkan sejauhmana alat untuk penelitian mampu mengukur variable yang terdapat dalam suatu penelitian. Dengan kata lain validitas merupakan suatu ukuran yang menunjukkan tingkat akurasi suatu alat ukur. Suatu alat ukur yang salah mempunyai validitas rendah, begitu pula sebaliknya.

Pengujian validitas alat ukur yang digunakan dalam peneltiain ini adalah pendekatan korelasi Pearson Product Momen yang meliputi empat tahapan yaitu :

\section{1) Penentuan Nilai Korelasi}

Untuk menentukan nilai korelasi digunakan rumus sebagai berikut :

$$
r=\frac{n \Sigma X_{1} Y_{1}-\left(\Sigma X_{1}\right)\left(\Sigma Y_{1}\right)}{\sqrt{\left[n \Sigma \mathrm{x}_{1^{2}}-\left(\Sigma X_{1}\right)^{2} \mid n \Sigma Y_{1^{2}}-\left(\Sigma Y_{1}\right)^{2}\right]}}
$$

$$
\begin{array}{ll}
r & =\text { Koefisien Korelasi } \\
X & =\text { Jumlah skor item ke-1 } \\
Y & =\text { Skor total seluruh item } \\
n & =\text { Jumlah responden }
\end{array}
$$

\section{2) Penentuan Uji Signifikan Korelasi Product Moment (t hitung)}

Untuk menentukan uji signifikasi korelasi Product Moment, secara statistic angka korelasi yang diperoleh diuji $\mathrm{t}$ atau dibandingkan dengan $\mathrm{t}$ tabel dengan derajat $(\mathrm{db})=\mathrm{n}-2$ pada $\mathrm{a}=0.05$ dengan menggunakan rumus sebagai berikut :

Keterangan :

$$
t=\frac{r \sqrt{n-2}}{\sqrt{1-r^{2}}}
$$

$r \quad=$ adalah koefisien korelasi

$n \quad=$ adalah jumlah responden

\section{3) Kaidah Keputusan}

(Iskandar, $2005: 29$ )

Nilai t-hitung yang dihasilkan kemudia dibandingkan dengan nilai t-tabel. Untuk kesalahan $5 \%(\alpha=0,05)$ dan derajar kebebasan $(\mathrm{dk})=\mathrm{n}-2$, setelah dibandingkan kemudian diambil keputusan dengn kaidah sebagai berikut:

1. Jika t-hitung $>\mathrm{t}_{\text {-tabel }}$ makan instrument tersebut valid.

2. Jika $\mathrm{t}_{\text {-hitung }}<\mathrm{t}_{\text {-tabel }}$ maka instumen tersebut tidak valid.

Dilihat dari kiteria maka pengujian, yaitu bahwa koefisien validitas dianggap signifikan apabila harga $t_{\text {hitung }}$ lebih besar dari tabel $(1-\alpha)(n-2)$ dengan harga parameter $\mathrm{p} \alpha 0.05$. alat ukut yang signifikan adalah valid, sedangkan yang tidak signifikan adalah tidak valid atau harus di drop.

Hasil pengujian menunjukkan bahwa instrument untuk variable X1 dari 20 butir pertanyaan ada satu pertanyaan yang tidak valid, sehingga instrument yang digunakan untuk variable X1 sebanyak 19 butir. Untuk instrument variable X2 dari 20 butir pertanyaan 18 pertanyaan yang 
dinyatakan valid, dan untuk variable Y dari 20 pertanyaan 19 pertanyaan yang menunjukkan butir pertanyaan yang valid.

\section{c. Pengujian Reliabilitas Alat Ukur Penelitian}

Untuk menguji reliabilitas alat ukur, terlebih dadhulu dicari harga korelasi secara keseluruhan dengan menggunakan korelasi Product Moment menurut Pearson (dalam Dajan, 2002 :376). Adapun rumus yang digunakan adalah sebagai berikut:

$$
r=\frac{n \sum X_{1} Y_{1}-\left(\Sigma X_{1}\right)\left(\Sigma Y_{1}\right)}{\sqrt{\left[n \sum \mathrm{X}_{1^{2}}-\left(\Sigma X_{1}\right)^{2} \mid n \Sigma Y_{1^{2}}-\left(\Sigma Y_{1}\right)^{2}\right]}}
$$

Keterangan :

$r \quad=$ koefisien korelasi

$\Sigma \mathrm{x} \quad=$ jumlah skor ganjil

$\Sigma \mathrm{y} \quad=$ jumlah skor genap

$n \quad=$ jumlah responden

Kemudian untuk mencari koefisien reliabilitasnya digunakan rumus Alfa Cronbach sebagai berikut :

$$
r=\left\{\frac{k}{k-1}\right\}\left\{1=\frac{\sum S_{1^{2}}}{S_{1^{2}}}\right\}
$$

Keterangan :

$$
\begin{array}{ll}
r & =\text { Reliabilitas alat ukur } \\
k & =\text { Banyaknya butir pertanyaan } \\
\sum S_{1^{2}} & =\text { Jumlah varian butir/item } \\
S_{1^{2}} & =\text { vaarian nilai total }
\end{array}
$$

Selanjutnya dilakukan penghitungan nilai statistiknya dengan rumus :

Keterangan :

$$
t=\frac{r \sqrt{n-2}}{\sqrt{1-r^{2}}}
$$

$t=$ nilai hitung

$r=$ koefisien korelasi hasil hitung

$n=$ jumlah responden

Untuk menarik keputusan maka digunkaan acuan sebagai berikut :

Bila $t_{\text {hitung }}>t\left(\frac{1}{2} \alpha, n-2\right)$ alat ukur reliable

Bilai $t_{\text {hitung }}<t\left(\frac{1}{2} \alpha, n-2\right)$ alat ukur tidak reliable

Hasil pengujian menunjukkan bahwa ketiga instrument yang akan digunakan sebagai alat ukur dalam penelitian ini memiliki tingkat reliabilitas yang tinggi.

\section{Teknik Pengolahan Data}

Teknik pengolahan data yang digunakan dalam penelitian ini yakni sebagai berikut :

1. Deskripsi variable, dengan maksud untuk menggambarkan kondisi setiap variable berdasarkan jawaban dari responden dengan menggunakan pendekatan statistic dengan distribusi sebaran frekuensi sederhana dalam bilangan prosentase kuantitafim yang mengacu pada pedoman interprestasi sebagai berikut :

Pedoman Penarikan Interpretasi Efektivitas Kuantitias Jawaban Responden 


\begin{tabular}{|c|l|}
\hline Rentang & Kriteria \\
\hline$n>\bar{X}+1,5 \mathrm{~S}$ & Sangat Baik \\
\hline $\bar{X}+0,5 S<n<\bar{X}+1,5 S$ & Baik \\
\hline $\bar{X}-0,5 S<n<\bar{X}+0,5 S$ & Cukup Baik \\
\hline $\bar{X}-1,5 S<n<\bar{X}-0,5 S$ & Kurang Baik \\
\hline$N<\bar{X}-1,5 S$ & Tidak Baik \\
\hline
\end{tabular}

\section{Catatan :}

$$
\begin{array}{ll}
n & =\text { skor atau nilai } \\
\bar{X} & =\text { rata-rata } \\
S & =\text { standar deviasi }
\end{array}
$$

2. Pengukuruan besarnya hubungan (korelasi) antar variable berdasarkan rumusan masalah dan hipotesis penelitian dengan menggunakan Uji $r$ dan dibantu dengan fasilitas Microsoft Excel ver.2007 dan program software SPSS ver.16 yang kemudian diinterpretasikan berdasarkan teori dari Suigoyono (2009), untuk hubungan menghitung hubungan atara $\mathrm{X}_{1 \mathrm{ke}} \mathrm{Y}$ dan $\mathrm{X}_{2}$ ke $\mathrm{Y}$.

\section{HASIL DAN PEMBAHASAN}

\section{Pengaruh Pelaksanaan KKG terhadap Peningkatan Mutu Sekolah}

Rumusan hipotesis yang diajukan adalah : "Pelaksanaan KKG berpengaruh positif terhadap peningkatan mutu sekolah". Untuk menjawab hipotesis yang diajukan tersebut,maka dilakukan pengujian, yaitu dengan menggunakan pengujian analisis jalur. Berdasarkan hasil pengujian diperoleh nilai koefisien jalur sebesar 0,718 .

Untuk mengetahui labih lanjut dampak variable X1 terhadap Y, maka dilakukan pengujian yaitu dengan melihat perbandingan antara $t_{\text {hitung }}$ dan $t_{\text {tabel }}$. Berdasarkan pengujian diperoleh nilai $t_{\text {hitung }}$ lebih besar dari nilai $t_{\text {tabel }}\left(t_{0,975 ; 135}\right)$ yaitu $t_{\text {hitung }}=11,968 t_{\text {tabel }}=1,9693$. Dari nilai tersebut diperoleh keputusan, bahwa pelaksanaan KKG (X1) mempunyai pengaruh positif terhadap peningkatan mutu sekolah (Y).

Signifikansi nilai hasil pengujian di atas, didukung pula oleh besaran nilai Koefisien Determinasi $I\left(R^{2}\right)$ sebesar $=0,5155$. Nilai ini menunjukkan bahwa pelaksanaan KKG (X1) memiliki pengaruh pqsitif dengan besarnya kontribusi terhadap peningkatan mutu sekoalh (Y) sebesar $51,55 \%$ sedangkan sisanya $\left(P_{\mathrm{Fg}}\right)^{2}$ sebesar $48,45 \%$ disebabkan oleh variable lainnya diluar variable pelaksanaan KKG yang tidak dimasukkan kedalam model.

Hasil pengujian analisis regresi menunjukkan bahwa kaitan keduanya ditentukan dengan persamaan regresi linier yaitu $\hat{Y}=36,295+0,622$ X1 artinya bahwa setiap kenaikan atau penuruan pada variable pelaksanaan KKG maka anak diikuti pula oleh kenaikan dan penurunan variable peningkatan mutu sekolah.

\section{Pengaruh Supervisi Rutin Kepala Sekolah (X2) terhadap Peningkatan Mutu Sekolah (Y)}

Rumusan hipotesis yang diajukan adalah : "Supervisi rutin kepada sekolah berpengaruh positif terhadap peningkatan mutu sekolah". Untuk menjawab hipotesis yang diajukan tersebut, maka dilakukan pengujian, yaitu dengan menggunakan pengujian analisis jalur. Berdasarkan hasil pengujiam diperoleh nilai koefisien jalur sebesar 0,762 .

Untuk mengatahui lebih lanjut pengaruh vaiabel X2 terhadap Y, maka dilakukan 
pengujian, yaitu dengan melihat perbandingan anatara $t_{\text {hitung }}$ dan $t_{\text {tabel. }}$. Berdasarkan pengujian diperoleh nilai $t_{\text {hitung }}$ lebih besar dari nilai $t_{\text {tabel }}\left(t_{0,975 ; 135}\right)$ yaitu $t_{\text {hitung }}=13,653>t_{\text {tabel }}=1,9693$. Dari nilai tersebut diperoleh keputusan, bahwa supervise rutin kepala sekolah (X2) mempunyai pengaruh positif terhadap peningkatan mutu sekolah (Y).

Signifikansi nilai hasil pengujian diatas, didukung pula oleh besaran nilai Koefisien Determinasi $\left(R_{Y 2 X}^{2}\right)$ sebesar $=0,5806$. Nilai ini menunjukkan bahwa Supervisi Rutin Kepala Sekolah (X2) memiliki pengaruh positif dengan besarnya kontribusi terhadap Peningkatan Mutu Pendidikan (Y) sebesar 56,06\%, sedangkan $\left(P_{\mathrm{Fg}}\right)^{2}$ sebesar 41,94\% disebabkan oleh variable lainnya dilaur variable Supervisi Kepala Sekolah yang tidak dimasukkan kedalam metode.

Hasil pengujian analisis regresi menunjukkan bahwa kaitan keduannya ditentukan dengan persamaan regresi linier yaitu $\hat{Y}=24,595+0,775 \mathrm{X} 2$ artinya bahwa setiap kenaikan atau penurunan pada variable supervise kepala sekolah maka akan diikuti pula oleh kenaikan dan penurunan pada variable peningkatan mutu sekolah.

\section{Pengaruh Pelaksanaan KKG (X1) dan Supervisi Rutin Kepala Sekolah (X2) terhadap Peningkatan Mutu Sekolah (Y)}

\section{a. Pengujian Secara Simultan}

Secara simultan, pengaruh variable pelaksanaan KKG (X1) dan Supervisi Rutin Kepala Sekolah (X2) terhadap Peningkatan Mutu Sekolah (Y) memiliki pengaruh yag signifikan. Ini diperlihatkan dari hasil pengujian variable $\mathrm{X} 1$ dan $\mathrm{X} 2$ terhadap $\mathrm{Y}$ menunjukkan adanya pengaruh yang signifikan, karena $F_{\text {hitung }}$ yang diperoleh lebihbesar dari $F_{\text {tabel }}\left(\mathrm{F}_{0,052 ; 262}\right)$ yaitu $F_{\text {hitung }}=125,665$ dan $F_{\text {tabel }}=3,04$. Hal ini berarti bahwa variable pelaksanaan KKG (X1) dan Supervisi Kepala Sekolah (X2) secara simultan (bersama-sama) memiliki pengaruh positif terhadap Peningkatan Mutu Sekolah (Y).

Signifikansi nilai hasil pengujian diatas, didukung pula oleh Koefisien Determinasi $\mathrm{R}^{2}$ sebesar $=0,6530$. Nilai ini menunjukkan bahwa peningkatan mutu sekolah (Y) dipengaruhi oleh pelaksanaan KKG (X1) dan supervise rutin kepala sekolah (X2) sebesar 65,3\% sedangkan sisanya $\left(P_{\mathrm{Zg}}\right)^{2}$ sebesaraa $34,70 \%$ dipengaruhi oleh variable lainnya diluar pelaksanaan KKG dan supervise rutin kepala sekolah.

Berdasarkan hasil pengujian diatas maka diketahui secara simultan variable X1 dan $\mathrm{X} 2$ memiliki pengaruh positif terhadap variable $\mathrm{Y}$, maka langkah berikutnya dapat dilakukan pengujian hipotesis secara parsial pada masing-masing varibael X1 dan X2 terhadap Y. Hasil pengujian analisis regresi menunjukkan bahwa kaitan keduannya ditentukan dengan persamaan

regresi linier yaitu $\hat{Y}=19,450+0,320 \mathrm{X} 1+0,518 \mathrm{X} 2$ artinya bahwa setiap kenaikan atau penurunan pada variable pelaksanaan KKG dan supervise kepala sekolah maka akan diikuti pula oleh kenaikan dan penurunan pada variable peningkatan mutu sekolah.

\section{b. Pengujian Secara Parsial}

Secara parsial, (1) pelaksanaan KKG memiliki pengaruh yang positif terhadap peningkatan mutu sekolah, dengan asumsi bahwa supervise rutin kepala sekolah dikendalikan (dianggap sama); dan (2) supervise rutin kepala sekolah memiliki pengaruh positif terhadap peningkatan mutu pendidikan, dengan asumsi pelaksanaan KKG dikendalikan (dianggap sama). Sebagai pembuktian terhadap hipotesis tersebut, maka dilakukan pengujian secara individu melalui Uji-t student. Hasil pengujian hipotesis tersebut dapat dilihat pada tabel berikut ini.

Hasil Analisis Koefisien Jalur X1 dan X2 dengan Y Secara Parsial 


\begin{tabular}{|c|c|c|c|c|}
\hline Jalur & $\begin{array}{c}\text { Nilai Koefisien } \\
\text { Jalur }\end{array}$ & thitung & ttabel & Kesimpulan \\
\hline$P_{\mathrm{yx} 1}$ & 0,416 & 4,568 & 1,9693 & Signifikan \\
\hline $\mathrm{P}_{\mathrm{yx} 2}$ & 0,533 & 6,296 & 1,9693 & Signifikan \\
\hline
\end{tabular}

Secara statistic, dari hasil penngujian menunjukkan bahwa masing-masing variable pelaksanaan KKG (X1), dan supervise rutin kepala sekolah (X2) memiliki pengaruh positif terhadap peningkatan mutu sekolah $(\mathrm{Y})$. signifikansi ini ditunjukkan dengan nilai $\mathrm{t}_{\text {hitung }}$ lebih besar daripada $t_{\text {tabel. }}$

Variable pelaksanaan KKG (X1) memiliki nilai $t_{\text {hitung }}$ yang lebih besar daripada $t_{0,975}$ yang berarti bahwa secara parsial, pelaksanaan KKG memiliki pengaruh positif terhadap peningkatan mutu sekolah (Y). demikian pula dengan variable supervise kepala sekolah (X1) memiliki nilai $t_{\text {hitung }}$ yang lebih besar daripada $\mathrm{t}_{0,975}$ yang berarti bahwa secara parsial, supervise kepala sekolah (X1) ememiliki pengaruh positif terhadap peningkatan mutu sekolah (Y).

\section{Pengaruh Pelaksanaan KKG terhadap Peningkatan Mutu Sekolah}

Hasil pengujian statistic diketahui bahwa pelaksanaan Kelompok Kerja Guru (KKG) memiliki pengaruh terhadap peningkatan mutu sekolah. Besarnya kontribusi yang ditandai dengan besarnya koefisien determinasi pengaruh pelaksanaan KKG terhadap peningkatan mutu sekolah diperoleh sebesar 51,55\%. Artinya lebih baik setengahnya peningkatan utuh sekolah akan ditemukan oleh pelaksanaan Kelompok Kerja Guru.

\section{Pengaruh Supervisi terhadap Peningkatan Mutu Sekolah}

Dari hasil pengujian diketahui bahwa supervise rutin kepala sekolah memiliki pengaruh positif secara nyata terhadap peningkatan mutu sekolah. Besarnya koefisien determinasi pengaruh antara supervise rutin kepala sekolah terhadap peningkatan mutu sekolah adalah sebesar 58,06\% sedangkan factor lain diluar varibel supervise kepala sekolah adalah sebesar $41,94 \%$.

\section{Pengaruh Pelaksanaan KKG dan Supervisi Rutin Kepala Sekolahterhadap Peningkatan Mutu Sekolah}

Dari hasil pengujian bahwa secara simultan (bersama-sama) pelaksanaan KKG dan supervisi rutin kepala sekolah memiliki pengaruh positif terhadap peningkatan mutu sekolah. Koefisien hubungan secara simultan pelaksanaan KKG dan supervisi rutin kepala sekolah terhadap peningkatan mutu sekolah adalah sebesar 65,30\% sedangkan dampak diluar varibael pelaksanaan KKG dan supervisi rutin kepala sekolah adalah sebesar 34,70\%.

Hasil perhitungan di atas menunjukkan bahwa secara bersama-sama pelaksanaan Kelompok Kerja Guru (KKG) dan supervisi rutin kepala sekolah mempunyai pengaruh yang tinggi terhadap peningkatan mutu sekolah. Kondisi ini secara teoritis dapat dijelaskan dengan didasarkan pada keterikatan kepala sekolah dalam upaya mempengaruhi perilaku orang lain terutama bawahannya untuk melakukan berbagai kegiatan yang mendukung tercapainya tujuan organisasi. Di samping itu pelaksanaan supervisi yang didasari pada konsepsi yang benar mampu meningkatkan keterikatan antara seluruh personal sekolah, khususnya antara kepala sekolah dengan guru.

\section{KESIMPULAN DAN SARAN}

Kesimpulan yang dapat ditarik dari hasil penelitian dan pembahasan mengenai pengaruh pelaksanaan Kelompok Kerja Guru (KKG) dan supervise rutin kepala sekolah terhadap peningkatan mutu sekolah dasar yang ada di Kecamatan Garut Kota Kabupaten Garut, antara 
lain:

1. Variabel-variabel yang dikaji dalam penelitian ini menunjukkan bahwa:

a. Variable pelaksanaan Kelompok Kerja Guru (KKG), berdasarkan hasil tanggapan responden menunjukkan pelaksanaan yang cukup baik. Hasil ini menunjukkan bahwa pelaksanaan KKG di Kecamatan Garut Kota selama ini dirasakan oleh guruguur belum optimal, sehingga perlu ada upaya untuk lebih meningkatkan berbagai kegiatan yang bermanfaat bagi pengembangan profesionalisme guru.

b. Variable supervise rutin kepala sekolah menunjukkan kriteria cukup baik. Kondisi ini menunjukkan bahwa secara umum kepala SD yang ada di Kecamatan Gsrut Kota belum sepenuhnya melaksanakan supervise ruti sebagaimana yang seharusnya. Supervise yang dilaksanakan selama ini masih dilaksanakan secara incidental dan belum dilakukan secara terpogram dengan baik.

c. Mutu sekolah juga menunjukkan kriteria cukup. Peningkatan mutu pendidikan ini ditunjukkan dengan beberapa komponen yang berhubungan dengan akreditasi sekolah, baik yang berhubungan dengan penataan kelembagaan, kurikulum, pelaksanaan pembelajaran, kelengkapan sarana dan prasarana, maupun komponen keterlibatan masyarakat dalam prosespendidikan di sekolah.

2. Ahasil pengujian hipotesis penelitian dapat disimpulkan bahwa pelaksanaan KKG dan supervise rutin kepala sekolah memiliki pengaruh positif terhadap peningkatan mutu sekolah dasar yanga da di Kecamatan Garut Kota Kabupaten Garut.

Berdasarkan kesimpulan dan beberapa permasalahan yang ditemukan selama penelitian, peneliti mencoba merekomendasikan hal-hal sebagai berikut:

1. Kelompok Kerja Guru, sebagai wadah tempat aktivitas guru dalam meningkatkan potensi dan profesionalisme guru, perlu meingkatkan baik kuantitas maupun kualitas kegiatannya, sehingga mampu memberikan manfaat yang besar bagi pengembangan pendidikan di sekolah. Disamping itu KKG sebagai sumber penyebaran informasi juga diperlukan adanya sumber informasi yang akurat dan bersifat menyeluruh, sehingga guru mampu memiliki inovasi terhadap pelaksanaan pembelajaran yang baik. Hal ini dapat dilakukan dengan meningkatkan kegiatan yang lebih bermutu dan mengintensifkan pertemuan secara rutin.

2. Kepala sekolah sebagai pimpinan di sekolah harus senantiasa aktif dan inovatif dalam melaksanakan supervise dalam berbagai bentuk, baik supervise kelas, maupun supervise klinis. Disamping itu perlu pula dilakukan tindak lanjut dari hasil supervise, yang menyangkut berbagai kekurangan dan bantuan apa yang diperlukan oleh guru.

3. Mutu sekolah sebagai suatu bentuk keberhasilan pelaksanaan pendidikan di sekolah, perlu mendapat perhatian yang serius dari seluruh komponen sekolah, sehingga mutu sekolah mampu mencapai standar mutu yang diharapkan. Oleh karena itu diperlukan upaya konkrit dari kepala sekolah sebagai pimpinan dalam memberikan bantuan, pengawasan, pembinaan, korektif, serta adanya tindak lanjut dari pelaksanaan pengawasan yang dilakukannya. Sementara itu bagi guru sebagai pelaksana pembelajaran perlu pula senatiasa meningkatkan kualitas dan kompetensi dirinya sehingga mampu mencapai guru yang professional secara nyata. Bagi siswa diharapkan juga memiliki motivasi yang tinggi dalam mengikuti pembelajaran, sehingga pengetahuan dan kecakapan yang disampaikan guru dapat diterimanya dengan baik.

\section{DAFTAR PUSTAKA}


[1] A Piet Sahertian, Konsep Dasar dan Teknik Supervisi, Jakarta : Penerbit Rineka Cipta, 2008

[2] Alfian (1997). Profesionalisme Guru dan Kualitas Pendidikan. http://m-ali.net/

[3] Supriadi (1998) Mengangkat Citra dan Martabat Guru. Yogyakarta : Adi Cita Hayu Nusa

[4] Peraturan Pemerintah Republik Indonesia Nomor 28 Tahun 1990 Tentang Pendidikan Dasar. Jakarta : Mensesneg.

[5] Depdikbud. (1995) Pola Pembaharuan Sistem Pendidikan tenaga Kependdidikan di Indoensia, Jakarta: Depdikbud

[6] A. Tabrani Rusyan, dkk, Pendekatan dalam Proses Belajar Mengajar, (Bandung: Remaja Karya)

[7] Soetjipto (dkk). 1994. Profesi Keguruan. Jakarta : Proyek Pembinaan dan Peningkatan Mutu Tenaga kependidikan. Direktorat Jenderal Pendidikan Tinggi. Departemen Pendidikan dan Kebudayaan.

[8] Undang-Undang RI Nomor 20 Tahun 2003 tentang system pendidikan nasional. Jakarta : Depdiknas.

[9] Anwar, I. (2004), Administrasi Pendidikan dan Manajemen dan Manajemen Biaya Pendidikan, Bandung : Alfabeta.

[10] Boardman, (1953) Supervising Instruction in Secondary Schools. New York. McGraw-Hill Books Company Inc

[11]Iskandar, J. (2005). Metode Penelitian Administrasi. Bandung: Puspaga. Kerlinger, Fred N (200) Asas-asas Penelitian: Behavior. (alih Bahasa Landung) 